\title{
Perception of the Online Learning Process during the Covid-19 Pandemic at New Higher Education Institution in Aceh
}

\author{
${ }^{1}$ Nabila Hilmy Zhafira, ${ }^{* 2}$ Amsal Irmalis \\ ${ }^{1}$ Management, Economic Faculty, Universitas Teuku Umar, Indonesia, \\ ${ }^{2}$ Management, Economic Faculty, Universitas Teuku Umar, amsal.irmalis@utu.ac.id
}

Submitted: 15/04/2021 Revised: 17/04/2021 Accepted: 25/04/2021

How to cite this article: Zhafira, N.H \& Irmalis, A. (2021). Perception of the Online Learning Process during the Covid-19 Pandemic at New Higher Education Institution in Aceh. IJELR: International Journal of Education, Language, and Religion, 3(1), 43-48.

\begin{abstract}
The expansion of access to education in Indonesia through new higher education institution or PTN-B gives new hope for the future of education. However, the limited condition of human resources, facilities, and infrastructure management processes of each PTN-B greatly impacts the learning process. The diversity of learning methods is present as an alternative solution to these problems, but is not sufficient to accommodate all learning needs. There are three PTN-B in Aceh, Universitas Teuku Umar, ISBI Aceh, and Universitas Samudra. The three PTN-Bs have carried out a learning process outside the network during the Covid-19 pandemic, but this is a relatively new phenomenon in the era of the COVID-19 pandemic. This is a challenge for PTN-B in Aceh, especially to face the COVID-19 era and anticipate global challenges in the future. This study aims to analyze students' perceptions of the application of online learning at PTN-B in Aceh during the Covid-19 pandemic, as well as to find out the assessment procedures for distance learning that have proven to be effectively applied to students according to the conditions/characteristics of students and the characteristics of learning materials. Then this study will evaluate the online learning process through student perceptions and make recommendations for its implementation. This study uses a literature review approach by emphasizing the analysis on numerical data that is processed by literature review methods
\end{abstract}

Keywords

Perception, Online learning, PTN-New

\section{Introduction}

New Higher-Education Institution $(P T N-B)$ provides new hope for the expansion of access to education in Indonesia. Indonesia has 4,670 universities, including PTA, PTK, PTS and PTN. The number of higher education coordinator groups in Indonesia is dominated by private and foreign universities, especially PTs with high school education, which amounts to 2,500. This is in contrast to the number of state universities which are only 122 consisting of 63 universities, 43 polytechnics, 12 institutes and 4 community academies (pdddikti, 2021). This condition prompted the government to increase the number of state universities in Indonesia so that the government converted some private universities into state universities. In the Presidential Decree signed by President Jokowi on February 1, 2016, it was stated that there were 35 private universities that had turned into new universities.

The condition of each new institution is very different, the readiness of human resources, facilities and management of the use of internet media is very diverse, of course this will have an impact on the 
learning process on campus. Generally, new higher education institution has limited resources, especially mastery of information systems, internet and e-learning related to the implementation of the learning process.

Then, learning methods at universities do not always have to be held face-to-face. There are other learning models that are more popularly used by teaching staff as a medium for delivering knowledge, namely online learning and mixed learning (a combination of two learning methods, namely face-toface and online learning).

However, full online learning is still considered less accommodating to all learning needs (Tuncay et al, 2011), so blended learning is an alternative that is quite attractive to teaching staff. Of course this online learning must be supported by internet facilities and adequate online media for all students as well as lecturers and education staff to increase student satisfaction. Thus, students will have a good perception of the online learning process that is carried out.

Basically, online learning methods do not require students to be present in class. Students can access learning through internet media. According to Lashley (2014) the use of technology available around us, if balanced with discussions and guidance, will become a tool for developing higher-order thinking skills. The development of this technology makes it easier to use the internet to access learning materials, interact with content, instructors, and other students; and to gain support during the learning process, to acquire knowledge, to construct personal meaning, and to grow from the learning experience. Generally, every lecturer in a university has their own considerations to choose which learning model is considered the most suitable to be held in student learning.

In connection with the Covid-19 outbreak in early 2020, the government then issued an appeal to carry out learning activities from home (Fajrian, 2020). This is done in order to break the chain of virus spread and maintain the security and safety of students and educators. This further strengthens the reason for the learning process activities to be carried out from home by utilizing technology and internet media. Several higher education institutions that previously conducted face-to-face learning on their respective campuses, now have to adapt to the e-learning or online learning model. Online learning provides benefits for both parties, both lecturers and students (Singh, 'donoghue, \& Worton, 2005). For students, online learning appears as an alternative method of learning that does not require them to be present in class. Online learning will also help students form independent learning and also encourage interaction between students. As for the lecturers of online learning methods, they are here to change conventional teaching styles which will indirectly have an impact on work professionalism. The online learning model also provides more opportunities for lecturers to assess and evaluate the learning progress of each student more efficiently.

PTN-B in Aceh during the Covid-19 pandemic has carried out a learning process outside the network, but this is a relatively new phenomenon in the era of the COVID-19 pandemic. Currently both educators and students are struggling with their respective implementations and adaptations. This is a challenge for PTN-B in Aceh, especially to face the COVID-19 era and anticipate global challenges in the future. The importance of this research is the first step to develop innovation learning and to find out student perceptions, especially for new PTNs that have limited resources on online lectures using different media.

\section{Method}


This study uses a literature review approach, namely by emphasizing the analysis on data that is processed by the method of reviewing various literacy documents. Some literature discusses perceptions and specifically about perceptions related to learning. The assessment was carried out based on several things such as; internet use and knowledge about online learning itself, students' perceptions of the benefits of online learning, and challenges in using online learning. The author uses descriptive research methods because this research penelitian has the aim of obtaining answers related to opinions, a person's response or perception so that the discussion must be qualitative or using descriptive words. "Descriptive research tries seek accurate and sufficient descriptions of all activities, objects, processes, and human. Data is a source of information obtained by the author through research conducted. The data obtained will be processed so that new information that can be used by readers. In this study, data were obtained through two sources, namely primary data and primary data secondary. This study will assess three new universities in Aceh Province, namely Universitas Teuku Umar, ISBI Aceh, and Universitas Teuku Umar. Data collection techniques are very needed in a study because it is used by the author to get the data to be processed so that conclusions can be drawn. There are various data collection techniques commonly used in conducting research.

Literature study of listening techniques can be divided into several techniques, including note-taking techniques. The note-taking technique is a technique of collecting data by using journals, books, and literature or library materials, then taking notes or quoting the opinions of experts in the book to strengthen the theoretical foundation in research. This note-taking technique uses books, literature, and library materials that are relevant to the research done, can usually be found in the library or at the author's place conduct research.

\section{Results and Discussion}

Online lectures are formal education organized by universities in which students and instructors (lecturers) are located in separate locations, thus requiring an interactive telecommunications system to connect the two and the various resources required in it. Its application is done by delivering material via the internet. This makes it easier for students to save more time and energy. Students consider online lectures conducted during the pandemic to be quite effective in reducing the spread of the COVID-19 virus, although they are also still doubtful because there is still no picture of what the lectures will look like. The majority of students also think that online lectures during this pandemic are quite good because they can gather with family (Wijayanengtias \& Claretta, 2020).

Perceptions of online lectures lead to learning models obtained from several approaches, learning media in online lectures, learning communication models, learning styles, and the effectiveness of online lectures. So it takes a lot of preparation starting from the infrastructure to the readiness of the institution to support the online lecture process. Online learning conducted at the university level generally uses a variety of online media. There are several online learning media with a fairly large percentage of use such as Google Classroom, Whatsapp, Zoom, and Edmodo (Maskar \& Wulantina, 2019).

Students have positive perceptions about the use of Google Classroom (Liu, H.-C., \& Chuang, 2016). Online learning using Google Classroom can increase interaction in the learning process, can access and communicate with classmates and teachers easily (Maskar \& Wulantina, 2019), Google Classroom's comparative performance is much better in the areas of communication, interaction, perceived benefits, convenience usage, and overall student satisfaction (Shaharanee, Jamil, \& Rodzi, 2016) so that the learning objectives were assessed as being achieved.

The use of Whatsapp as an online online medium is considered easy and simple, the network supports it, it is not complicated compared to other applications, it saves data packages and is not too difficult if 
the network is not supported (Anhusadar, 2020). The instant messaging feature of Whatsapp is a free application, this is also considered beneficial for its users. Mobile system text messaging allows users to send and receive messages synchronously and asynchronously. Whatsapp has a simple, intuitive, and very easy to use messaging system (Amry, 2014). Not only is it easy to send messages to each other in written form but also in the form of photos, videos or audio, besides that Whatsapp does not require a lot of internet quota to be accessed among students (Maulah, Nurul, \& Ummah, 2020). This will greatly facilitate the interaction between lecturers and students in online learning activities.

Zoom Cloud Meeting is considered by some students to be very helpful in learning activities and makes it easier for students to access learning with a fairly good quality of student interaction and communication because of the real time method that this application has. However, the percentage of students who agree that Zoom Cloud Meeting improves the quality of learning is only $37 \%$, this is because new students are adapting to online learning based on Zoom Cloud Meeting (Liu \& Ilyas, 2020). Compared to Google Classroom and Whatsapp, the Zoom Meeting application is considered less stable regarding its internet connection, so it will often be disconnected while participating in online learning. The effective use of Zoom Cloud Meetings is very dependent on the internet network, especially if the respondents are in the outermost areas of Indonesia. In terms of the ease of collecting assignments, Zoom Cloud Meeting is in the medium category, while Google Classroom is in the good category because Google Classroom has a feature for submitting assignments directly by students in every assignment given by the lecturer (Brahma, 2020; Maulana, 2021).

In the era of the Industrial Revolution 4.0, lecturers as teaching staff are expected not to stutter about technology. Technology basically provides expectations to become a unity in learning so that students are created who are more creative, active and independent. Educators/teaching staff are currently very much required to utilize information and communication technology as their learning needs, if this is not fulfilled, it could be that educators/teaching staff will be left behind with the times (Prajana \& Astuti, 2020). Various models of material delivery can also be used by lecturers as teaching staff to help students understand and review the material to be studied. The interactive discussions that were previously conducted face-to-face must be replaced with the help of various applications that are limited in the form of audio-visual materials in the form of images, modules, power points, tutorials, and others. Audiovisual media is considered to be able to replace the role of lecturers as facilitators in the online learning process (Saragih, Sebayang, Sinaga, \& Ridlo, 2020). In addition, the design of the learning curriculum, and effective delivery are also very much needed to be able to optimize these online learning activities. However, there are some students who mention complaints or shortcomings such as facilities, networks, task intensity, and in terms of the depth of the material (Wijayanengtias \& Claretta, 2020). In fact, more than $50 \%$ of students agree that they are not happy with the decision to extend the study period from home or study online. The lack of a study quota and the weak internet network in the environment where they study causes students to not be able to participate in learning optimally so that the course material is not fully understood. Face-to-face learning is considered more optimal in understanding learning and the teaching and learning process directly or offline is something that is greatly missed. (Noviantari \& Payadnya, 2021).

The most significant barriers include the lack of student knowledge and skills in the use of e-learning, and lack of access to devices and internet connections (Mailizar, Almanthari, Maulina, \& Bruce, 2020). Especially for some remote areas it is difficult to obtain a smooth internet network. Similar findings from other studies are the high cost of participating in online learning which shows that students outside China because of Covid-19 spent so much money buying internet data for online learning (Demuyakor, 2020). 


\section{Conclusion}

There is a positive perception of students regarding the implementation of online lectures, especially in the aspects of the teaching and learning process and lecturer capabilities. This is inseparable from the ability HR manages online lectures which in this case is the lecturer as a facilitator. However, it was also found that students had negative perceptions in the aspect of facilities and infrastructure related to the limitations of the internet network and learning tools owned by students (Saragih, Sebayang, Sinaga, \& Ridlo, 2020). Therefore, online lectures should be carried out with the support of an adequate platform and the presentation of material that is comprehensive, easy to understand, and easily accessible so that students' knowledge and skills do not decrease.

\section{References}

Amry, A. B. (2014). The impact of Whatsapp Mobile Social Learning on The Achievement and Attitudes of Female Students Compared with Face to Face Learning in The Classroom. European Scientific Journal, 10(22), 116-136

Anhusadar, L. ode. (2020). Persepsi Mahasiswa Piaud Terhadap Kuliah Online di Masa Pandemi Covid 19. KINDERGARTEN: Journal of Islamic Early Childhood Education, 3(1), 44-58.

Brahma, I. A. (2020). Penggunaan Zoom Sebagai Pembelajaran Berbasis Online Dalam Mata Kuliah Sosiologi dan Antropologi Pada Mahasiswa PPKN di STKIP Kusumanegara. Jakarta. Aksara: Jurnal Ilmu Pendidikan Nonformal. https://doi.org/10.37905/aksara.6.2.97-102.2020 Davison, R. M., Martinsons, M. G., Kock N., (2004), Journal : Information Systems Journal : Principles of Canonical Action Research, 14, 65-86

Demuyakor, J. (2020). Coronavirus (Covid-19) and Online Learning in Higher Institutions of Education: A Survey of The Perceptions of Ghanaian International Students in China. Online Journal of Communication and Media Technologies, 10(3),

Liu, A. N., \& Ilyas. (2020). Persepsi Mahasiswa Dalam Implementasi Pembelajaran Online Berbasis Zoom Cloud Meeting Program Studi Pendidikan Fisika Universitas Flores. OPTIKA: Jurnal Pendidikan Fisika, 85-90.

Liu, H.-C., \& Chuang, H.-H. (2016). Integrating Google Classroom to Teach Writing in Taiwan. Minnesota eLearning Summit.

Mailizar, Almanthari, A., Maulina, S., \& Bruce, S. (2020). Secondary School Mathematics Teachers' Views on E-learning Implementation Barriers During the Covid-19 pandemic: The Case of Indonesia. Eurasia Journal of Mathematics, Science and Technology Education, 16(7).

Maulah, S., Nurul, F., \& Ummah, N. R. (2020). Persepsi Mahasiswa Biologi terhadap Perkuliahan Daring Sebagai Sarana Pembelajaran Selama Pandemi Covid-19. ALVEOLI: Jurnal Pendidikan Biologi, 50-61.

Maulana, H. A. (2021). Persepsi Mahasiswa terhadap Pembelajaran Daring di Pendidikan Tinggi Vokasi: Studi Perbandingan antara Penggunaan Google Classroom dan Zoom Meeting. EDUKATIF: Jurnal Ilmu Pendidikan, 188-195.

Maskar, S., \& Wulantina, E. (2019). Persepsi Peserta Didik terhadap Metode Blended Learning dengan Google Classroom . Jurnal Inovasi Matematika, 1(2), $110 \pm 121$. https://doi.org/10.35438/inomatika.v1i2.156

Ningsih, S. (2020). Persepsi Mahasiswa Terhadap Pembelajaran Daring Pada Masa Pandemi Covid-19. JINOTEP (Jurnal Inovasi Teknologi Pembelajaran), 124-132.

Noviantari, P. S., \& Payadnya, I. P. (2021). Persepsi Mahasiswa Terhadap Kuliah Daring Pada Masa Pandemi Covid 19. Jurnal Pembelajaran dan Pengembangan Matematika, 13-22.

Nugroho. (2012). Profesionalisme Guru SD Negeri Se-Kecamatan Warungasem KAbupaten Batang. Suatu tinjauan aspek persepsi guru tentang kepemimpinan kepala sekolah dan motivasi berprestasi guru. Varidika, 135-146 
Parek. (1984). Metode Belajar dan Kesulitan-kesulitan Belajar. Bandung: Tarsito. Walgito, B. (2010). Pengantar Psikologi Umum . Yogyakarta: Andi Offset

Prajana, A., \& Astuti, Y. (2020). Pemanfaatan Teknologi Informasi dan Komunikasi dalam Pembelajaran oleh Guru SMK di Banda Aceh dalam Upaya Implementasi Kurikulum 2013.

Saragih, O., Sebayang, F. A., Sinaga, A. B., \& Ridlo, M. R. (2020). Persepsi Mahasiswa Terhadap Pembelajaran Daring Selama Pandemi Covid 19. Tarbiyah Wa Ta'lim: Jurnal Penelitian Pendidikan \& Pembelajaran, 178-191.

Shaharanee, I. N. M., Jamil, J. M., \& Rodzi, S. S. M. (2016). Google Classroom as a Tool for Active Learning. in AIP Conference Proceedings (Vol. 1761). https://doi.org/10.1063/1.4960909

Tuncay, N., Stanescu, I. A., \& Tuncay, M. (2011). A Different Vision in eLearning: Metaphors. Electronic Journal of e-Learning, 9(1), 105-113.

Wijayanengtias, M., \& Claretta, D. (2020). Student Perceptions of Online Learning During the Covid19 Pandemic. Kanal: Jurnal Ilmu Komunikasi, 16-21.

Zimmerman, B., \& Martinez-Pons, M. (1988). Construct validation of a strategy model of student selfregulated learning. Journal of Educational Psychology, Vol. 80, 284- 290.

Zimmerman, B. (2000). Attaining selfregulation: A social cognitive perspective. In M. Boekarts, P. R. Pintrich, \& M. Zeidner (Eds.), Handbook of selfregulation (pp. 13- 39). San Diego, CA: Academic Press. 